\title{
ACCURACY INCREASE OF SOFTWARE AND HARDWARE APPLIANCE FOR MUSCLE ACTIVITY MEASURING AND MONITORING BY FILTRATION OF CARRIER COMPONENT AND FREQUENCIES HIGHER THAN MEASURED SIGNAL RANGE
}

ITMO University, Saint Petersburg, 197101, Russian Federation

Corresponding author: itgavrilov@gmail.com

Article info

Received 02.06.20, accepted 01.07.20

Article in English

For citation: Gavrilov S.A., Kyzdarbekova A.S., Reznikov S.S. Accuracy increase of software and hardware appliance for muscle activity measuring and monitoring by filtration of carrier component and frequencies higher than measured signal range. Scientific and Technical Journal of Information Technologies, Mechanics and Optics, 2020, vol. 20, no. 4, pp. 617-624 (in English). doi: $10.17586 / 2226-1494-2020-20-4-617-624$

\section{Abstract}

Subject of Research. The paper proposes a method of muscle activity filtering measurements for a mobile hardwaresoftware appliance used in surface electromyography. The method extends the dynamic range of measurements by capacity growth of analog-to-digital converter aimed at the increase of recognition accuracy and range of muscle activity. Method. A filter model for signals from sensors for a muscle activity controller was developed in the Proteus Design Suite software package. The filter of the signal carrier component based on the RC high-pass filter provides isolation of the measuring unit from the reference voltage of the sensor. An active low-pass filter amplifies the signal from the sensor and filters out the noise higher than the frequency range of muscle activity signals. Main Results. Filtering of the signal carrier component and increasing the order of low-pass filter show positive results in simulation. The paper presents amplitude-frequency characteristics plots and model structures with and without RC filter, with an active low-pass filter of the first order and an active low-pass filter of the second order. An amplifier unit electrical circuit for a muscle activity controller is developed based on the methodology for muscle activity measurement filtering. The results obtained are applicable for improvement of the prototype for the mobile hardware-software appliance used in surface electromyography. Practical Relevance. The developed complex can be applied in a system for muscle activity measuring and monitoring as the rehabilitation process maintenance during the movement of patients with injuries and disorders of the musculoskeletal system. This complex can be used in various neurophysiological studies where the monitoring of muscle activity dynamics in the process of the examined subject movement is required.

Keywords

surface electromyography, surface EMG, muscle activity measurement, EMG signal high-pass filter, EMG signal active low-pass filter, neurocomputer interface

doi: 10.17586/2226-1494-2020-20-4-617-624

\section{ПОВЫШЕНИЕ ТОЧНОСТИ ПРОГРАММНО-АППАРАТНОГО КОМПЛЕКСА ДЛЯ ИЗМЕРЕНИЯ И РЕГИСТРАЦИИ МЫШЕЧНОЙ АКТИВНОСТИ ФИЛЬТРАЦИЕЙ НЕСУЩЕЙ СОСТАВЛЯЮЩЕЙ И ЧАСТОТ ВЫШЕ ИЗМЕРЯЕМОГО ДИАПАЗОНА СИГНАЛА}

\section{С.А. Гаврилов, А.С. Кыздарбекова, С.С. Резников}

Университет ИТМО, Санкт-Петербург, 197101, Российская Федерация

Адрес для переписки: itgavrilov@gmail.com

Информация о статье

Поступила в редакцию 02.06.20, принята к печати 01.07.20

Язык статьи - английский

Ссылка для цитирования: Гаврилов С.А., Кыздарбекова А.С., Резников С.С. Повышение точности программно-аппаратного комплекса для измерения и регистрации мышечной активности фильтрацией несущей составляющей и частот выше измеряемого диапазона сигнала // Научно-технический вестник информационных технологий, механики и оптики. 2020 . Т. 20 . № 4. С. 617-624 (на англ. яз.). doi: 10.17586/2226-1494-2020-20-4-617-624 


\begin{abstract}
Аннотация
Предмет исследования. Предложена методика фильтрации измерений мышечной активности для мобильного программно-аппаратного комплекса интерференционной электромиографии. Рассмотрен метод повышения динамического диапазона измерений за счет увеличения разрядности аналогово-цифрового преобразования для повышения точности и диапазона распознавания мышечной активности. Метод. Разработана модель фильтра сигналов от датчиков для контроллера мышечной активности в программном пакете Proteus Design Suite. Фильтр несущей составляющей сигнала на основе RC-фильтра высоких частот обеспечивает отвязку блока измерения от опорного напряжения датчика. Активный фильтр низких частот усиливает сигнал от датчика и фильтрует шумы выше диапазона частот сигналов мышечной активности. Основные результаты. Фильтрация несущей составляющей сигнала и повышение порядка фильтра низких частот, в моделировании показали положительные результаты. Приведены графики амплитудно-частотных характеристик и схемы моделей без RC-фильтра и с ним, с активным фильтром низких частот первого порядка и активным фильтром низких частот второго порядка. На основе методики фильтрации измерений мышечной активности разработана электрическая схема блока усиления для контроллера мышечной активности. Полученные результаты применены для модернизации прототипа мобильного программно-аппаратного комплекса интерференционной электромиографии. Практическая значимость. Областью применения разрабатываемого комплекса может быть система измерения и регистрации мышечной активности для сопровождения процесса реабилитации при движении пациентов с травмами и нарушениями работы опорно-двигательного аппарата. Данный комплекс может быть применен в различных нейрофизиологических исследованиях, где требуется отслеживание динамики мышечной активности в процессе движения обследуемого.
\end{abstract}

Ключевые слова

интерференционная электромиография, иЭМГ, измерение мышечной активности, ФВЧ ЭМГ-сигнала, активный ФНЧ ЭМГ-сигнала, нейрокомпьютерный интерфейс

\section{Introduction}

The aim of this work is a theoretical study of methods for the accuracy increase of measuring muscle activity for a mobile hardware-software complex of surface electromyography (sEMG) [1]. This complex is being modernized as part of the development of a neurocomputer interface for controlling bionic devices, such as a prosthesis [2]. Earlier, a prototype of a hardware-software complex for recording muscle activity was presented. The prototype is based on a paraphrase sensor of muscle activity, a controller and computer software [3].

During the study of the developed prototype and other existing solutions, a number of parameters was identified that needed improvement:

1. increasing the capacity of the analog-to-digital converter for dynamic range growth,

2. increasing the resistance to external noise when working near the actuators of bionic devices.

In this regard, we set a number of requirements for the development of a hardware-software complex minimizing power consumption and mass-dimensional characteristics while maintaining measurement accuracy.

In the future, it is planned to develop a Bluetooth communication channel and an autonomous power supply unit on a lithium-polymer battery.

At the moment, there are a large number of various mobile systems for surface EMG such as "SportLab" domestic software and hardware complex from LLC "Biosoft" Scientific Medical Firm and "MIST" from LLC "Neurotech" Scientific Medical Firm or imported "Delsys Wireless EMG System". Similar systems are developed to a greater extent for the needs of professional sports or the introduction of anesthesia.

The primary, but incidental area of application of the mobile surface EMG complex that we are developing is a system for measuring and recording muscle activity at the rehabilitation process monitoring during the movement of patients with injuries and disorders of the musculoskeletal system $[4,5]$. Also, this complex can be used in various neurophysiological studies, where tracking the muscle activity dynamics in the process of the subject movement is required [6-9].

\section{Description of the model}

To test theoretically the effectiveness of the solutions used to upgrade the previously developed prototype [3] and to increase the accuracy of measuring muscle activity, a model was developed in the software package (PC) for the automated design of electronic circuits Proteus Design Suite release 8.9 SP2 (Build 28501) with advanced modeling.

The main changes affected the amplifier block are shown in Fig. 1. The model was built on the basis of a random signal source, the amplifier block model and virtual measuring instruments from the PP.

A script-generator was used as a source of a random signal, shown in Fig. 2 from the example of "Noise Generator" projects from the Sample Projects library supplied as part of the software. Output signal parameters are: amplitude $\pm 0.4 \mathrm{~V}$, frequency $2 \mathrm{kHz}$.

An equivalent amplifier circuit was also created and is shown in Fig. 3.

\section{Signal carrier component filtering. Isolation capacitor modernization}

An isolation capacitor was installed in the amplifier block of the prototype [3] at the signal input from the sensor (C16 in Fig. 1, C3 in Fig. 3). This capacitor gives the possibility to filter the carrier constant component of the signal and feed only the variable component to the input of the amplifier. Filtering of carrier constitute unties the measurement node from the sensor electrical circuit and provides an opportunity to avoid measurement distortions associated with voltage drops on the wires between the sensor and the amplification unit. Carrier decoupling also makes it possible to get rid of the need in midpoint 


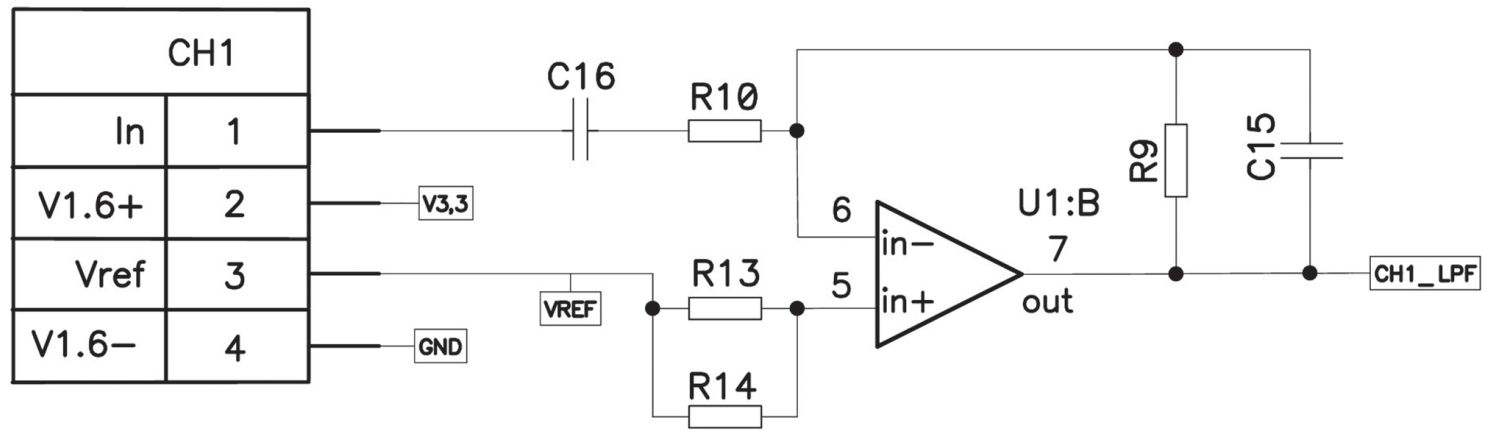

Fig. 1. The initial circuit of the prototype amplifier [3]

You may also change the value of BANDWIDTH property (in the *DEFINE block) to reduce/increase the noise frequecy bandwidth. You may also change the sample frequency in the SCRIPT at the line TIME FREQ=500us.

If you've got a slow PC or you increase the sample frequency then you may run an audio analysis to hear the noise off-line.

The Noise level can be modified by changing the voltage values at VREF+ and VREF- of the DAC1.

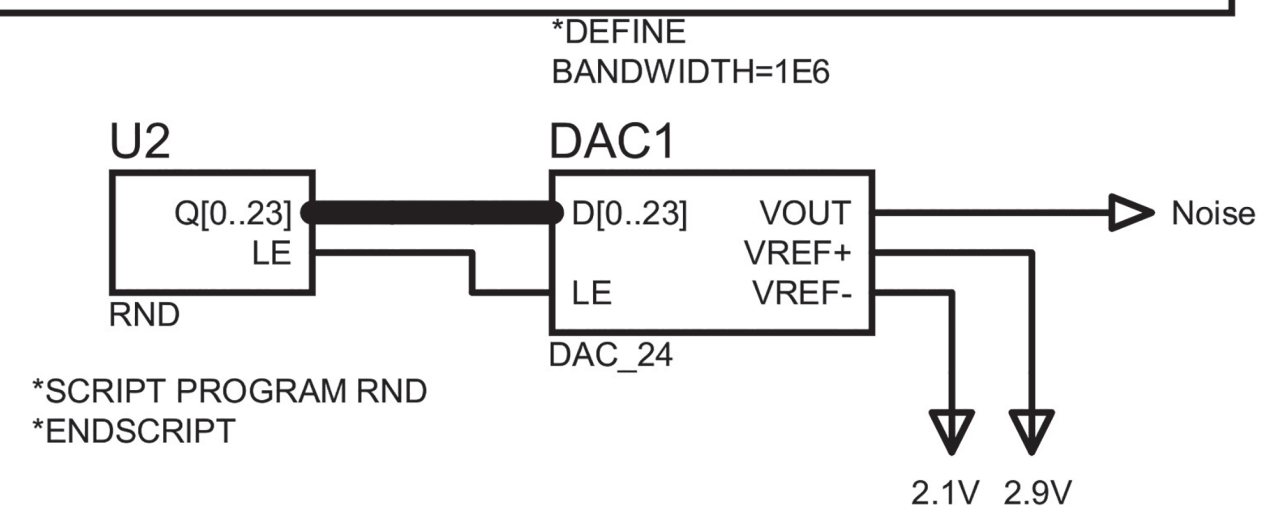

Fig. 2. Script-generator "Noise Generator"

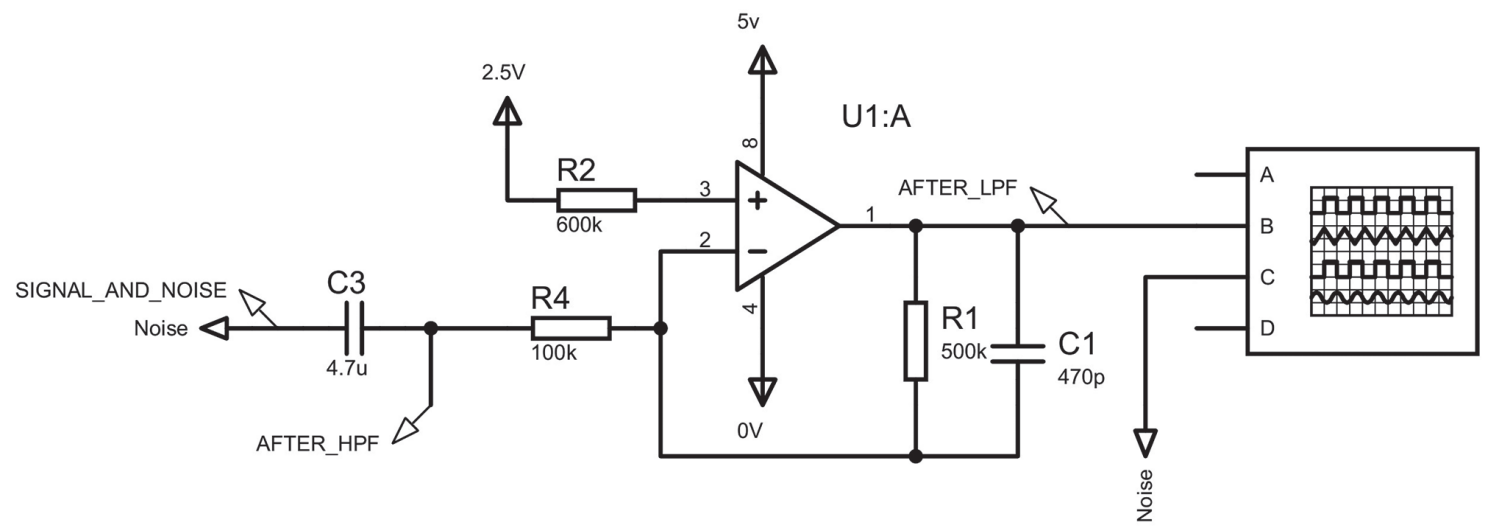

Fig. 3. Schematic of an equivalent prototype output filter model 
agreement on each sensor (reference level carrying voltage), connected to one controller and coordinate with one electrode from the controller.

Studies of the prototype and model were carried out and design error was identified. The model of the amplification unit in its original form, shown in Fig. 3, did not discharge the isolation capacitor C3 (in Fig. 3). In this regard, the isolation capacitor did not fulfill its main function - cutting off the carrier of the signal constant component. This can be seen on the graph of the amplitude-frequency characteristic (AFC) shown in Fig. 4. Also, incorrect operation of the low-pass filter (LPF) in the operational amplifier strapping was observed.

To solve the problem with isolation capacitor, a fullfledged high-frequency RC filter (HPF) was built up by means of installing the resistor R3 [10]. The connection diagram is shown in Fig. 5. The cut-off frequency of the $\mathrm{HPF}$ is found by the formula:

$$
\begin{aligned}
f_{H P F}=\frac{1}{2 \times \pi \times R 3 \times C 3} & =\frac{1}{2 \times 3.14 \times 24 \mathrm{kOhm} \times 4.7 \mu \mathrm{F}} \approx \\
& \approx 1.4109 \mathrm{~Hz},
\end{aligned}
$$

where $f_{H P F}$ is the cut-off frequency of the HPF; $\pi$ is a mathematical constant equal to the ratio of the circumference of a circle to its diameter; $R 3$ is the resistance of the resistor R3 (Fig. 3); C3 is the capacitance of the capacitor C3 (Fig. 3).

The result of replacing the isolation capacitor with $\mathrm{RC}$ HPF can be seen on the AFC - graph of the model shown in Fig. 6.

\section{Increasing the order of gain block active filter}

An active first-order LPF was built in the block of the prototype amplifier [3] on the basis of an operational amplifier (U1, C1, R1, R4 in Fig. 3, 5). As previously noted, the prototype showed incorrect filter operation. After installing a resistor R3 in the model, the efficiency of the LPF increased. This can be seen by comparing the graphs in Fig. 4, 6. The gain of the amplifier and the cutoff frequency of LPF are found by the formulas, respectively:

$$
G_{c h}=-\frac{R 1}{R 4}=-\frac{500 \mathrm{kOhm}}{100 \mathrm{kOhm}}=-5 \text {; }
$$

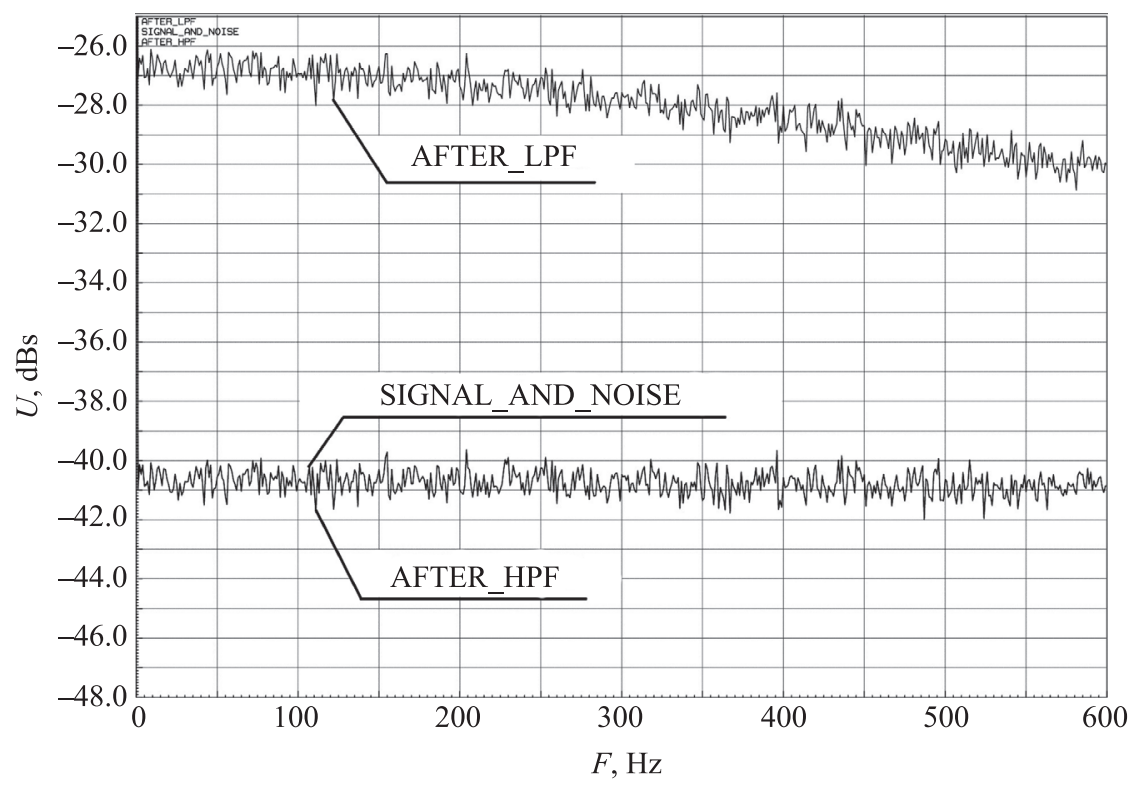

Fig. 4. The model AFC graph (references of measurement points in Fig. 3): SIGNAL_AND_NOISE - AFC input signal; AFTER_ HPF - AFC signal after HPF; AFTER_LPF - AFC signal after LPF

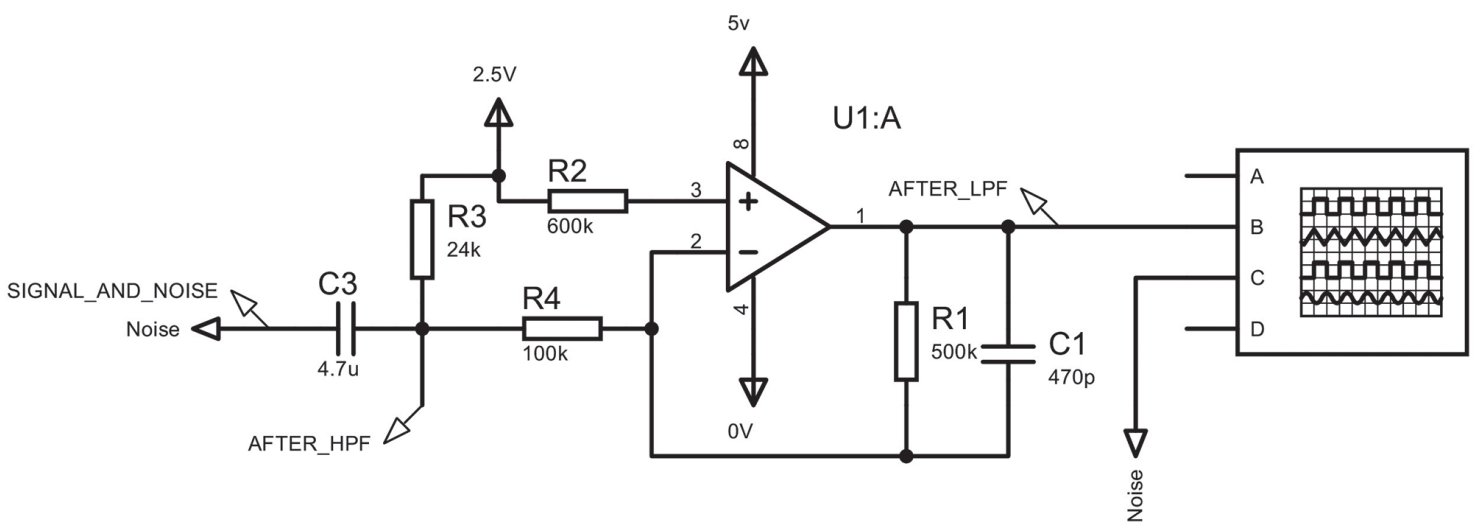

Fig. 5. Scheme of the amplifier model with RC-HPF input 


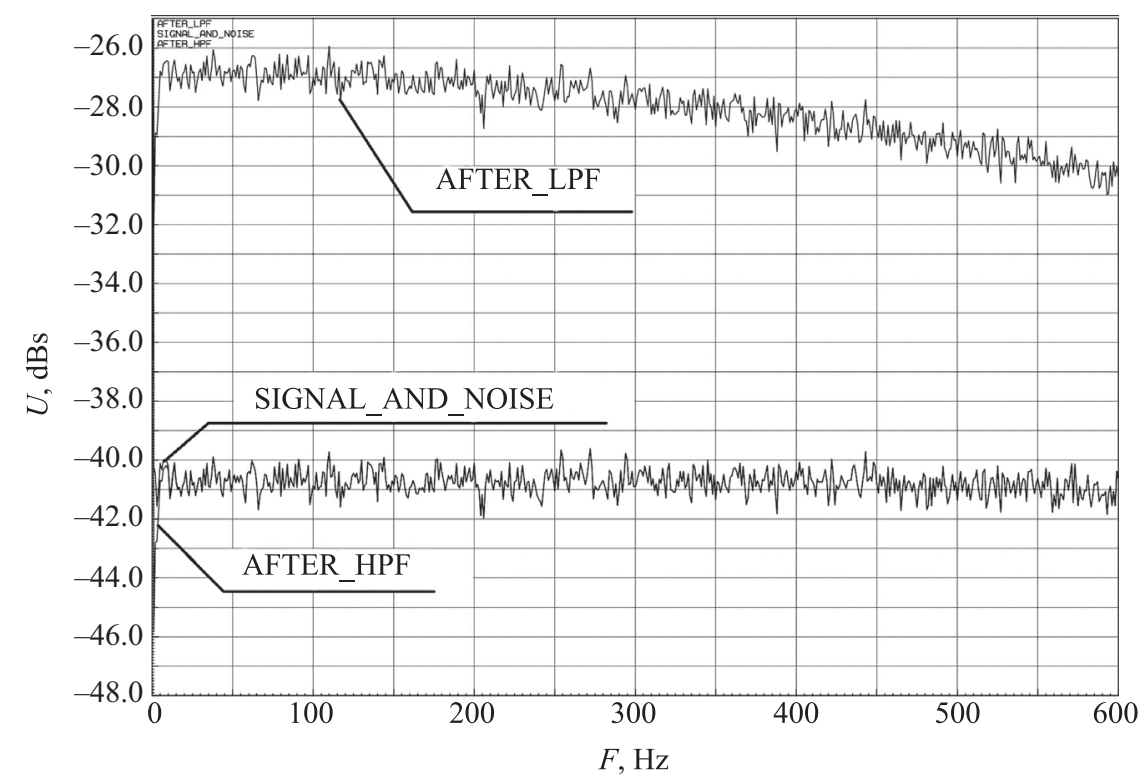

Fig. 6. AFC graph of the model with RC-HPF input (reference measurement points in Fig. 5)

$$
\begin{aligned}
f_{L P F}=\frac{1}{2 \times \pi \times R 4 \times C 1} & =\frac{1}{2 \times 3.14 \times 100 \mathrm{kOhm} \times 470 \mathrm{pF}} \approx \\
& \approx 677.25 \mathrm{~Hz},
\end{aligned}
$$

where $G_{c h}$ is the gain of the amplifier; $f_{L P F}$ is the cut-off frequency of the LPF; $R 1$ is the resistance of the resistor $\mathrm{R} 1$ (Fig. 5); $R 4$ is the resistance of the resistor R4 (Fig. 5); $C 1$ is the capacitance of the capacitor $\mathrm{C} 1$ (Fig. 5).

In the study of the developed prototype and other existing solutions, it was supposed that stability to external noise would not be enough when working near the actuators of bionic devices.

External noises outside the measured range with insufficient filtering can significantly distort the data.

In this regard, we decided to build the active LPF to the $2^{\text {nd }}$ order by replacing the denomination $\mathrm{R} 4$ and adding $\mathrm{R} 5$ and $\mathrm{C} 2$ [11]. The modernized model circuit is shown in Fig. 7. The gain and cutoff frequency have not changed and are found by the formulas, respectively:

$$
G_{c h}=-\frac{R 1}{R 4+R 5}=-\frac{500 \mathrm{kOhm}}{50 \mathrm{kOhm}+50 \mathrm{kOhm}}=-5 ;
$$

$$
\begin{gathered}
f_{L P F}=\frac{1}{2 \times \pi \times(R 4+R 5) \times C 1}= \\
\frac{1}{2 \times 3.14 \times(50 \mathrm{kOhm}+50 \mathrm{kOhm}) \times 470 \mathrm{pF}} \approx \\
\approx 677.25 \mathrm{~Hz},
\end{gathered}
$$

where $R 4$ is the resistance of the resistor $\mathrm{R} 4$ (Fig. 7); $R 5$ is the resistance of the resistor R5 (Fig. 7).

The value of the capacitor $\mathrm{C} 2$ is found by the formula:

$$
C 2=\frac{4 \times R 1 \times C 1}{R 4+R 5}=\frac{4 \times 500 \mathrm{kOhm} \times 470 \mathrm{pF}}{50 \mathrm{kOhm}+50 \mathrm{kOhm}}=9.4 \mathrm{nF},
$$

where $C 2$ is the capacitance of the capacitor C2 (Fig. 7).

The AFC graphs compare the efficiency of active LPF of the $1^{\text {st }}$ and $2^{\text {nd }}$ orders in the frequency band $1.2 \mathrm{kHz}$, respectively, and are presented in Fig. 8.

A controller circuit and an equivalent model of the prototype amplifier are developed based on the obtained data and are shown in Fig. 9.

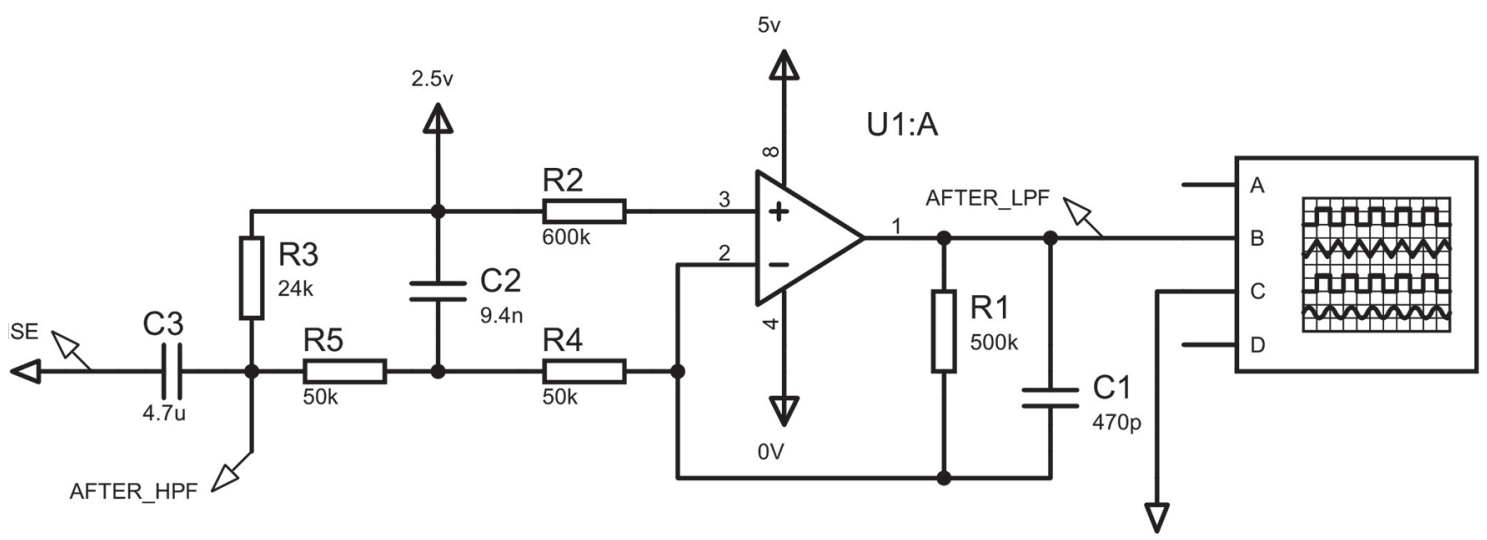

Fig. 7. Scheme of the model with the output active LPF of the 2 nd order 
$a$

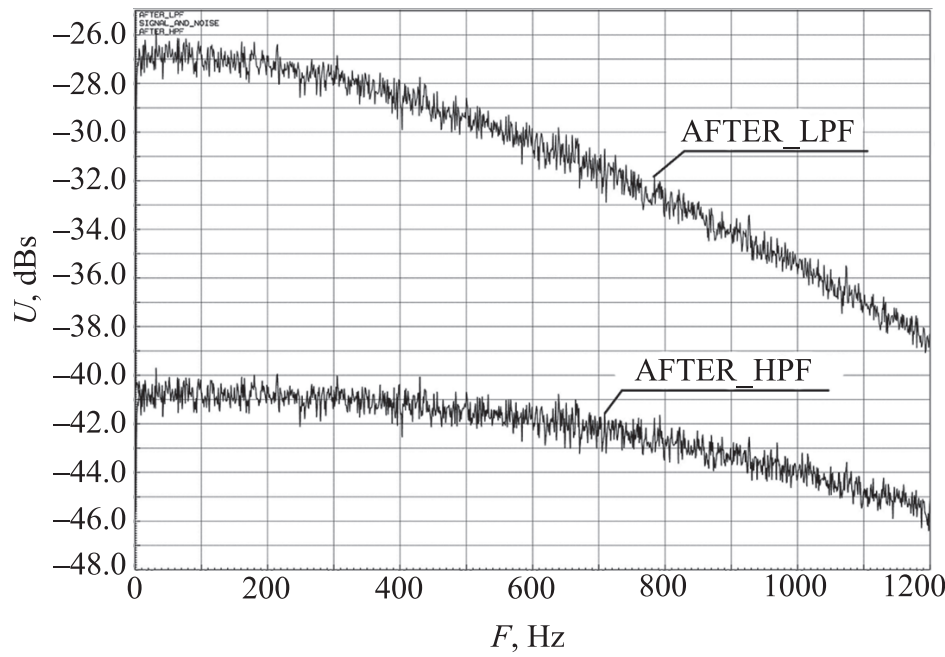

$\sigma$

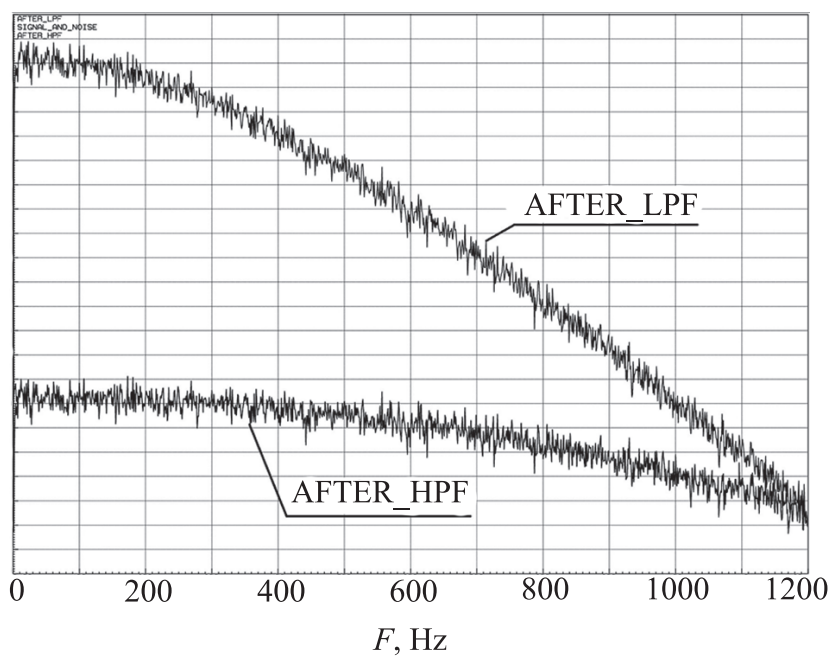

Fig. 8. Frequency response graphs: active $1^{\text {st }}$-order LPF $(a) ; 2^{\text {nd }}$-order LPF $(b)$

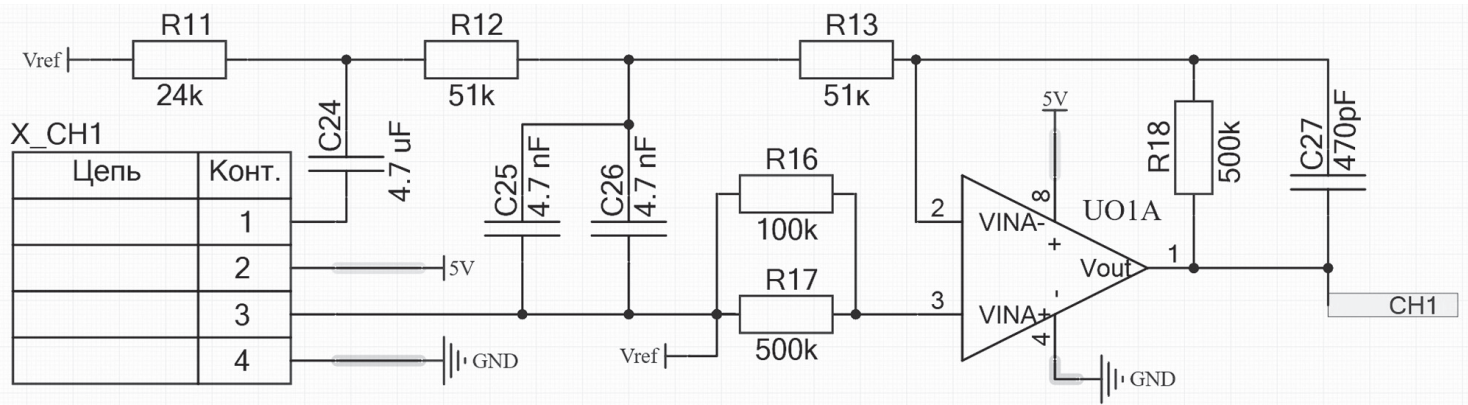

Fig. 9. An equivalent model of the prototype amplifier with HPF input and LPF active output of the second order

\section{Analog-to-digital conversion of muscle activity measurements}

In the prototype [3], analog-to-digital conversion (ADC) was carried out by means of a 12-bit ADC unit integrated in the STM32f405 microcontroller [12]. To increase the dynamic range of measurements, it was decided to use an external ADC microcircuit. For this purpose, the ADS1256 microcircuit (chip) was chosen [13].
The ADS1256 is an 8-channel 24-bit Delta-Sigma ADC chip with a programmable coefficient gain and a sampling rate of up to $30 \mathrm{kHz}$.

Programmable gain gives the possibility to develop and implement a dynamic gain adjustment algorithm that will positively affect the operational properties of the software and hardware complex.

The ADR03BRZ chip from Analog Devices [14] was selected as a voltage source of $2.5 \mathrm{~V}$ for ADS1256, and

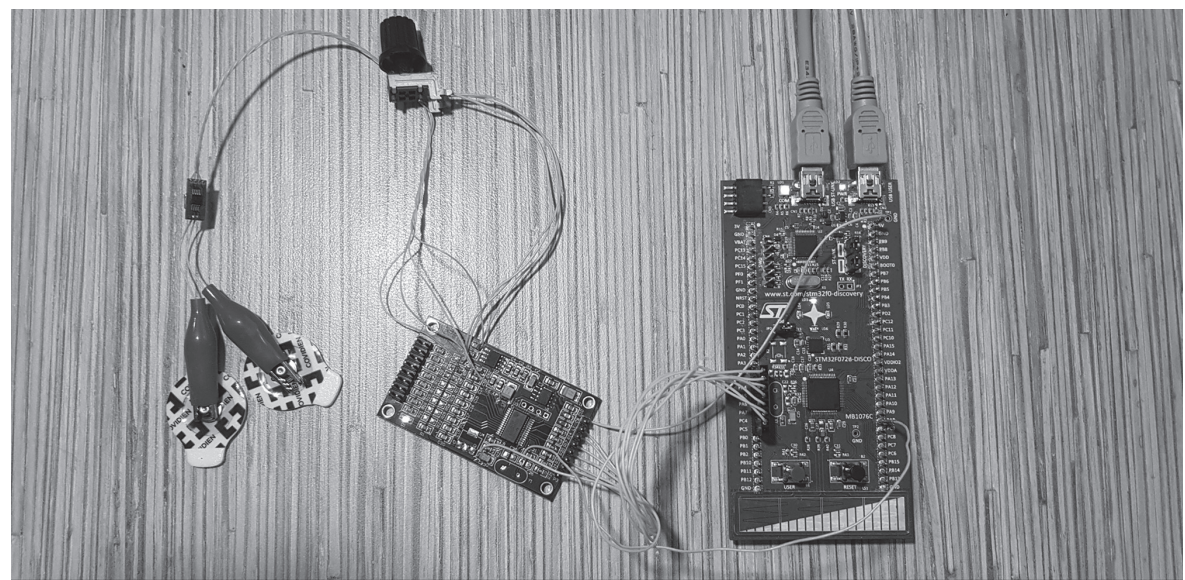

Fig. 10. Test layout for ADS1256 
the circuit based on OPA350UA [15] recommended by the manufacturer ADS1256 [13] was taken as a buffer for the voltage reference. The clocking of the ADS1256 is from STM32f405.

This solution was previously mocked up (Fig. 10) and the functionality was tested.

\section{Conclusion}

The results obtained are used to modernize the prototype of a mobile hardware-software complex of interference electromyography. A controller circuit and an equivalent model of a prototype amplifier are developed with an input high-pass filter and an output active low-pass filter of the second order.

Such methods as filtering the carrier component of the signal and increasing the order of the low-pass filter in the simulation have shown positive results in accuracy increase.

The dynamic range extension of measurements by increasing the bit depth of the analog-to-digital conversion and automatic gain control will improve the accuracy and range of muscle activity recognition.

\section{References}

1. Biomedical Signal Analysis. Ed. by R.M. Rangayyan. John Wiley \& Sons, 2015, 720 p. doi: 10.1002/9781119068129

2. Nowak M., Eiband T., Ramírez E. R., Castellini C. Action interference in simultaneous and proportional myocontrol: Comparing force- and electromyography. Journal of Neural Engineering, 2020, vol. 17, no. 2 , pp. 026011. doi: 10.1088/1741-2552/ab7b1e

3. Gavrilov S.A., Kyzdarbekova A.A. Hardware-software complex prototyping for muscle activity monitoring. Proc. VIII Congress of Young Scientists. Vol. 3. St. Petersburg, ITMO University, 2019 pp. 35-38. (in Russian)

4. Liu J., Ren Y., Xu D., Kang S.H., Zhang L.-Q. EMG-based real-time linear-nonlinear cascade regression decoding of shoulder, elbow, and wrist movements in able-bodied persons and stroke survivors. IEEE Transactions on Biomedical Engineering, 2020, vol. 67, no. 5, pp. 1272-1281. doi: 10.1109/tbme.2019.2935182

5. Potocnik B., Divjak M., Urh F., Francic A., Kranjec J., Savc M., Cikajlo I., Matjacic Z., Zadravec M., Holobar A. Estimation of muscle co-activations in wrist rehabilitation after stroke is sensitive to motor unit distribution and action potential shapes. IEEE Transactions on Neural Systems and Rehabilitation Engineering, 2020, vol. 28, no. 5, pp. 1208-1215. doi: 10.1109/TNSRE.2020.2980440

6. Pradhan A., Malagon G., Lagacy R., Chester V., Kuruganti U. Effect of age and sex on strength and spatial electromyography during knee extension. Journal of Physiological Anthropology, 2020, vol. 39, no. 1, pp. 11. doi: 10.1186/s40101-020-00219-9

7. Finsterer J. EMG-interference pattern analysis . Journal of Electromyography and Kinesiology, 2001, vol. 11, no. 4, pp. 231-246. doi: 10.1016/s1050-6411(01)00006-2

8. Ruonala V., Meigal A., Rissanen S.M., Airaksinen O., Kankaanpää M., Karjalainen P.A. EMG signal morphology and kinematic parameters in essential tremor and Parkinson's disease patients. Journal of Electromyography and Kinesiology, 2014, vol. 24, no. 2, pp. 300-306. doi: 10.1016/j.jelekin.2013.12.007

9. Meigal A., Fomina E. Electromyographic evaluation of countermeasures during the terrestrial simulation of interplanetary spaceflight in Mars500 project. Pathophysiology, 2016, vol. 23, no. 1 , pp. 11-18. doi: 10.1016/j.pathophys.2015.10.001

10. Horowitz P. Hill W. The Art of Electronics. $3^{\text {rd }}$ ed. Cambridge University Press, 2015, 1220 p.

11. Borisenko A.L. Circuitry of Analog Electronic Devices. Functional Units of Analog Devices. St. Petersburg, Polytechnic University Publ., 2016, 127 p. (in Russian)

12. Reference manual. STM32F405/415, STM32F407/417, STM32F427/437 and STM32F429/439 advanced Arm ${ }^{\circledR}$-based 32-bit MCUs. STMicroelectronics, 2019.

13. Data sheet for ADS1256. Very Low Noise, 24-Bit Analog-to-Digital Converter. Texas Instruments, 2013.

14. Data Sheet ADR01/ADR02/ADR03/ADR06 Ultracompact, Precision $10.0 \mathrm{~V} / 5.0 \mathrm{~V} / 2.5 \mathrm{~V} / 3.0 \mathrm{~V}$ Voltage References. Analog Devices, 2019.

15. Data sheet for OPAx350 High-Speed, Single-Supply, Rail-to-Rail Operational Amplifiers MicroAmplifier Series. Texas Instruments, 2015.

\section{Литература}

1. Biomedical Signal Analysis / ed. by R.M. Rangayyan. John Wiley \& Sons, 2015. 720 p. doi: 10.1002/9781119068129

2. Nowak M., Eiband T., Ramírez E. R., Castellini C. Action interference in simultaneous and proportional myocontrol: Comparing force- and electromyography // Journal of Neural Engineering. 2020. V. 17. N 2. P. 026011. doi: 10.1088/1741-2552/ab7b1e

3. Гаврилов С.А., Кыздарбекова А.А. Разработка прототипа программно-аппаратного комплекса для регистрации мышечной активности // Сборник трудов VIII Конгресса молодых ученых. Вып. 3. СПб., Университет ИТМО, 2019. С. 35-38.

4. Liu J., Ren Y., Xu D., Kang S.H., Zhang L.-Q. EMG-based real-time linear-nonlinear cascade regression decoding of shoulder, elbow, and wrist movements in able-bodied persons and stroke survivors // IEEE Transactions on Biomedical Engineering. 2020. V. 67. N 5. P. $1272-$ 1281. doi: 10.1109/tbme.2019.2935182

5. Potocnik B., Divjak M., Urh F., Francic A., Kranjec J., Savc M., Cikajlo I., Matjacic Z., Zadravec M., Holobar A. Estimation of muscle co-activations in wrist rehabilitation after stroke is sensitive to motor unit distribution and action potential shapes // IEEE Transactions on Neural Systems and Rehabilitation Engineering. 2020. V. 28. N 5. P. 1208-1215. doi: 10.1109/TNSRE.2020.2980440

6. Pradhan A., Malagon G., Lagacy R., Chester V., Kuruganti U. Effect of age and sex on strength and spatial electromyography during knee extension // Journal of Physiological Anthropology. 2020. V. 39. N 1. P. 11. doi: 10.1186/s40101-020-00219-9

7. Finsterer J. EMG-interference pattern analysis // Journal of Electromyography and Kinesiology. 2001. V. 11. N 4. P. 231-246. doi: 10.1016/s1050-6411(01)00006-2

8. Ruonala V., Meigal A., Rissanen S.M., Airaksinen O., Kankaanpää M., Karjalainen P.A. EMG signal morphology and kinematic parameters in essential tremor and Parkinson's disease patients // Journal of Electromyography and Kinesiology. 2014. V. 24. N 2. P. 300-306. doi: 10.1016/j.jelekin.2013.12.007

9. Meigal A., Fomina E. Electromyographic evaluation of countermeasures during the terrestrial simulation of interplanetary spaceflight in Mars500 project // Pathophysiology. 2016. V. 23. N 1. P. 11-18. doi: 10.1016/j.pathophys.2015.10.001

10. Horowitz P. Hill W. The Art of Electronics. $3^{\text {rd }}$ ed. Cambridge University Press, 2015. $1220 \mathrm{p}$

11. Борисенко А.Л. Схемотехника аналоговых электронных устройств. Функциональные узлы аналоговых устройств. СПб.: Изд-во Политехнического университета, 2016. 127 с.

12. Reference manual. STM32F405/415, STM32F407/417, STM32F427/437 and STM32F429/439 advanced Arm ${ }^{\circledR}$-based 32-bit MCUs. STMicroelectronics, 2019.

13. Data sheet for ADS1256. Very Low Noise, 24-Bit Analog-to-Digital Converter. Texas Instruments, 2013.

14. Data Sheet ADR01/ADR02/ADR03/ADR06 Ultracompact, Precision 10.0 V/5.0 V/2.5 V/3.0 V Voltage References. Analog Devices, 2019.

15. Data sheet for OPAx350 High-Speed, Single-Supply, Rail-to-Rail Operational Amplifiers MicroAmplifier Series. Texas Instruments, 2015. 


\section{Authors}

Stepan A. Gavrilov - Postgraduate, ITMO University, Saint Petersburg, 197101, Russian Federation, ORCID ID: 0000-0002-8743-2249, itgavrilov@gmail.com

Aidana S. Kyzdarbekova - Postgraduate, ITMO University, Saint Petersburg, 197101, Russian Federation, Scopus ID: 57200194065, ORCID ID: 0000-0001-7466-043X, aidanakyzdarbekova@gmail.com

Stanislav S. Reznikov - PhD, Associate Professor, Associate Professor, ITMO University, Saint Petersburg, 197101, Russian Federation, Scopus ID: 57194697899, ORCID ID: 0000-0001-6886-046X, stanich@mail.ru

\section{Авторы}

Гаврилов Степан Александрович - аспирант, Университет ИТМO, Санкт-Петербург, 197101, Российская Федерация, ORCID ID: 0000-0002-8743-2249, itgavrilov@gmail.com

Кыздарбекова Айдана Садвакасовна - аспирант, Университет ИТМО, Санкт-Петербург, 197101, Российская Федерация, Scopus ID: 57200194065, ORCID ID: 0000-0001-7466-043X, aidanakyzdarbekova@gmail.com

Резников Станислав Сергеевич - кандидат технических наук, доцент, доцент, Университет ИТМО, Санкт-Петербург, 197101, Российская Федерация, Scopus ID: 57194697899, ORCID ID: 0000-0001-6886-046X, stanich@mail.ru 